\title{
ESTABLISHMENT OF NUCLEAR STOCK COLLECTIONS FOR APPLE AND PEAR IN LATVIA
}

\author{
Neda Zuḷgge ${ }^{1, \#}$, Anna Kāle ${ }^{1}$, Alina Gospodaryk ${ }^{1,2}$, Kristīne Vēvere ${ }^{1}$, \\ and Inga Moročko-Bičevska ${ }^{1}$ \\ ${ }^{1}$ Institute of Horticulture, Latvia University of Agriculture, Graudu iela 1, Ceriṇi, Krimūnu pagasts, Dobeles novads, LV-3701, LATVIA \\ ${ }^{2}$ Educational and Scientific Centre, Institute of Biology and Medicine, Taras Shevchenko National University of Kyiv, \\ 64 Volodymyrska Street, Kiev, UKRAINE \\ \# Corresponding author, neda.zulge@ @lu.Iv
}

Communicated by Ludmila Vīksna

\begin{abstract}
Apples and pears are among the most important commercial fruit species grown in Latvia. Because of suitability to local climatic conditions, mainly domestic cultivars and cultivars originating in neighbouring countries are grown. The planting material of pome fruits produced and used for establishment of new orchards in Latvia corresponds to the Conformitas Agraria Communitatis standard due to the unavailability of nuclear stock. To establish virus-tested, experimental nuclear stock for apple and pear, one to two years old candidate plants were exposed to thermotherapy at $+38{ }^{\circ} \mathrm{C}$ for 40 to 70 days. The mother trees and candidate plants before treatment were tested for the presence of the four most widespread pome fruit viruses by RT-PCR. The shoot tips of the heat-treated plants were grafted onto seedling rootstocks and were re-tested for the four viruses by RT-PCR during the next three to five vegetation seasons. Several plants of apple cultivars 'Dace', 'Zarja Alatau', 'Rubin', and 'Ausma' remained infected either with Apple chlorotic leaf spot virus, Apple stem growing virus or Apple stem pitting virus after the thermotherapy. Tests on woody indicators were carried out to determine possible presence of graft-transmittable organisms according to EPPO guidelines for the establishment of nuclear stock material for pome fruits.

Key words: ACLSV, ASGV, ASPV, ApMV, Malus $\times$ domestica, Pyrus communis, RT-PCR, thermotherapy.
\end{abstract}

\section{INTRODUCTION}

Apple is a widely grown and commercially important fruit crop in Latvia, occupying about 9000 ha, of which more than 1300 ha are modern commercial orchards. The total area of pear orchards is 200 ha, of which commercial orchards represent only 122 ha (Skrivele et al., 2008). The first initiatives for the development of virus-free planting material in Latvia started in the 1970s when methods and measures for the propagation of healthy, virus-free planting material were applied (Kilevica et al., 1976; Svarcbahs et al., 1977). These initiatives were interrupted at the beginning of 1990s when the EU Marketing Directive 92/34/EC was approved (Anoymous, 1992b). During the past two decades, many commercial apple orchards have been established using introduced cultivars and clonal rootstocks. Pears are grown mainly on seedling rootstocks. Due to the specific requirements of adaptation to local climatic conditions, mainly domestic cultivars and cultivars originating in Russia, Belarus, Kazakhstan, and Lithuania have been used for establishment of new apple and pear orchards. Cur- rently, all orchards are established using planting material corresponding to Conformitas Agraria Communitatis (CAC) standard, the lowest category of quality for planting material (Reed and Foster, 2011; Skrivele and Kaufmane, 2015). Therefore, the risk of using infected planting material for establishment of new orchards is high.

Sixteen graft-transmittable organisms including viruses, viroids, phytoplasmas, and virus-like diseases in apple require testing and twelve diseases for pears, according to the European and Mediterranean Plant Protection Organisation (EPPO) certification scheme for pathogen-tested material (Anonymous, 1999). Apple chlorotic leaf spot virus (ACLSV), Apple mosaic virus (ApMV), Apple stem pitting virus (ASPV), and Apple stem grooving virus (ASGV) are the most widespread viruses on apple and pear with worldwide distribution, including in Latvia (Desvignes, 1999; Pupola et al., 2011). Infections by these viruses usually are latent; however, the growth, poor survival of grafted buds, and productivity of infected trees can be severely affected (Sutic et al., 1999; Cembali, 2003; Maxim et al., 2004; 
Waterworth and Hadidi, 2005; Lenz and Lankes, 2006). Causal agents are not known for several of the diseases of apple and pear that should be tested within the certification schemes, and in those cases the diseases can be tested only using woody indicator plants. These include fruit and bark deforming disorders, such as apple chat, pear bark necrosis, rubbery wood, flat limb, rouge skin, star crack and other graft-transmissible disorders (Fridlung et al., 1989; Anonymous, 1999).

A starting point for a production of virus-free planting material of fruit trees is the establishment and availability of virus-free mother trees or nuclear stock collections. The EPPO scheme defines two types of categories for healthy mother plants: (i) virus-free (VF), where the individual plants have been tested for all virus and virus-like pathogens and disorders; and (ii) virus-tested (VT), where only the most important pathogens have been inspected and tested (Anonymous, 1992a). The introduction of virus-free material from other countries is suggested as an alternative for the initiation of nuclear stock collections in cases where such material is not available in the particular country (Anonymous, 1999). However, if the import is from countries outside the EPPO region, the material should be tested for all other known viruses occurring in the particular region.

Healthy initial planting material can be obtained by elimination of viruses using thermotherapy, apical meristem cultures, chemotherapy and micrografting techniques or combining several methods (Svarcbahs et al., 1977; Howell et al., 1998; Cieslinska and Zawadzka, 1999; Sutic et al., 1999; Wang et al., 2006; Paprstein et al., 2008). Thermotherapy is a standard and widely used method to eliminate viruses from infected fruit trees. The temperatures applied and duration of heat treatments vary depending on the pathogen and plant species exposed to the thermotherapy (Posnette and Cropley, 1956; Campbell and Best, 1964; Cropley, 1968; Howell et al., 1998). The main limitations of this method are low tolerance of some genotypes of fruit trees to elevated temperatures, space required in the growth chambers for the needed quantity of treated material and lack of complete elimination of all viruses by thermotherapy (Mink et al., 1998; Sutic et al., 1999; Paprstein et al., 2008). Another efficient method for obtaining virus-free plants is propagation in vitro using apical meristem cultures, but its use in practice for trees is limited due to somaclonal variation (Ostry et al., 1994; Rani et al., 1995; Anonymous, 1999). Therefore, a mandatory demand in certification schemes is verification of trueness to type for fruit tree cultivars that have been propagated in vitro (Anonymous, 1999), significantly extending time and increasing the costs for the establishment of virus-free plants.

After sanitation procedures, each candidate plant for nuclear stock should be tested to confirm freedom of graft-transmissible diseases. Despite the availability of PCR-based detection methods for most of the pathogens listed, the use of woody indicators is still compulsory to verify freedom of fruit crops from graft-transmittable diseases (Anonymous, 1999; Jelkmann, 2001). The molecular detection methods can be used only for rapid screening of treated material, to confirm woody indicator test results and monitoring of health status of nuclear stock plants in the greenhouse (Reed and Foster, 2011; Thompson et al., 2011).

The initiative to produce virus-free planting material for fruit crops in Latvia was re-started by the Institute of Horticulture (LatHort; formerly Latvia State Institute of FruitGrowing) in 2005-2006. The alternative to introducing virus-free planting material as a pre-basic stock from other countries was not possible for apple and pear due to the lack of appropriate standard source for the majority of the cultivars needed. Therefore, sanitation procedures for cultivars of interest and development of experimental nuclear stock collections for apple and pear were started in 2006. The specific aims of this work were: (i) to evaluate and establish most suitable thermotherapy conditions for target apple and pear cultivars; (ii) to assess possibilities for sanitation of target apple and pear cultivars from the most widespread viruses; and (iii) to establish experimental nuclear stock collections for apple and pear.

\section{MATERIALS AND METHODS}

Plant material. Twenty-six apple cultivars and 16 pear genotypes, including introduced and local cultivars and perspective hybrids, were selected for sanitation and establishment of experimental nuclear stock collections, according to EPPO standard PM 4/27(1) (Anonymous, 1999). Propagation material was collected from trees in pomological field trials or germplasm collections at LatHort and Pūre Horticultural Experimental Station (Pūre HRS). Each year, starting from 2007, about ten apple and ten pear cultivars were budded on one-year old seedling rootstocks grown in containers filled with steam-sterilised peat substrate and maintained in an insect-proof greenhouse. Trails with cultivars that did not lead to establishment of candidate plants for several reasons (buds did not grow on rootstock, plants did not overwinter or did not survive thermotherapy) were repeated in the next year. The schematic presentation of steps and timing for establishment of experimental nuclear stock collections is shown in Figure 1.

Seventeen accessions of woody indicators were obtained from the Netherlands Inspection Service for Horticulture (Naktuinbouw) in 2010, propagated on one-year old seedling rootstocks and maintained in an insect-proof greenhouse.

To avoid frost damage to the potted candidate plants, they were kept in a greenhouse with heating to prevent decrease of ambient temperature below $-10{ }^{\circ} \mathrm{C}$. During winter, the greenhouse floor was covered with $5 \mathrm{~cm}$ thick foam plastic blocks. Containers with substrate were wrapped in rock wool and plants were covered with horticultural fleece. Starting from 2014, instead of rock wool, pots were insulated with polyethylene bubble-wrap and tops of the plants were wrapped in a double layer of horticultural fleece (density $17 \mathrm{~g} / \mathrm{m}^{3}$ ). 


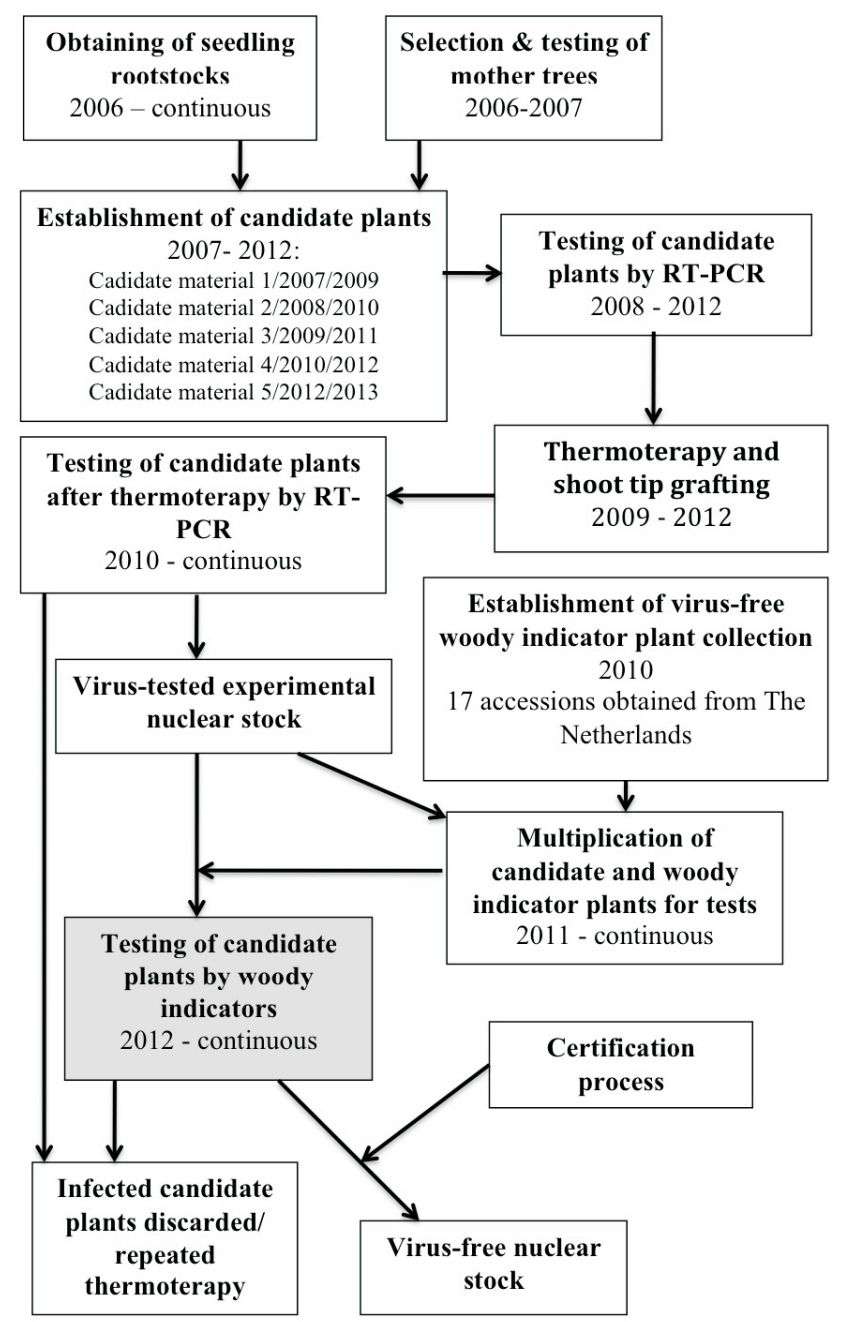

Fig. 1. The steps and time scale of establishment of experimental nuclear-stock collections for apple and pear; the filled square indicates the present stage of the work.

Thermotherapy. Two or one-year-old candidate plants were placed in growth chambers KBWF 240, KBWF 270 (Binder GmbH, Germany) and EKOCHL 1500 (Angelantoni Life Science, Italy) under a $16 \mathrm{~h}$ light and $8 \mathrm{~h}$ dark period, and humidity level $75 \%$. The conditions for thermotherapy for each year and plant species used are summarised in Table 1. In 2009, plants were maintained in heat-treatment for 40 days as recommended by several authors (Svarcbahs et al. 1977; Lenz and Lankes, 2006). In 2010 and 2011, the heat treatment period was prolonged to 70 days as suggested by Howell et al. (1998). In the next years, the treatment duration and temperature at night were reduced (Table 1). To prolong tree life during the heat therapy, at the beginning the trees were acclimatised for one week at $35^{\circ} \mathrm{C}$ during the day and $30{ }^{\circ} \mathrm{C}$ during the night, as previously recommended by Welsh and Nyland (1965). The duration of all treatments was calculated from the first day when temperature was elevated to $35^{\circ} \mathrm{C}$.

Shoot tips $(5 \mathrm{~mm})$ of heat-treated apple and pear plants were excised with a sterile blade and grafted onto vigorous seedling rootstocks 'Antonovka' or 'Kazraušu', respectively. Grafted plants were covered with glass jars to main-
Table 1

CONDITIONS AND DURATION OF HEAT-TREATMENTS FOR APPLE AND PEAR

\begin{tabular}{|c|c|c|c|c|}
\hline \multirow{2}{*}{$\begin{array}{l}\text { Candidate } \\
\text { material* }^{*}\end{array}$} & \multirow{2}{*}{$\begin{array}{c}\text { Year of } \\
\text { thermotherapy }\end{array}$} & \multirow{2}{*}{$\begin{array}{l}\text { Temperature } \\
\text { day/night, }{ }^{\circ} \mathrm{C}\end{array}$} & \multicolumn{2}{|c|}{ Duration, days } \\
\hline & & & Apple & Pear \\
\hline \multirow{4}{*}{$1 / 2007 / 2009$} & \multirow{4}{*}{2009} & $35^{\circ} \mathrm{C} / 30^{\circ} \mathrm{C}$ & 5 & 5 \\
\hline & & $38^{\circ} \mathrm{C} / 33^{\circ} \mathrm{C}$ & 10 & 10 \\
\hline & & $38^{\circ} \mathrm{C} / 38^{\circ} \mathrm{C}$ & 25 & 25 \\
\hline & & otal & 40 & 40 \\
\hline \multirow[t]{3}{*}{$2 / 2008 / 2010$} & \multirow[t]{3}{*}{2010} & $35^{\circ} \mathrm{C} / 30^{\circ} \mathrm{C}$ & 5 & 5 \\
\hline & & $38^{\circ} \mathrm{C} / 33^{\circ} \mathrm{C}$ & 65 & 65 \\
\hline & & otal & 70 & 70 \\
\hline \multirow[t]{3}{*}{$3 / 2009 / 2011$} & \multirow[t]{3}{*}{2011} & $33^{\circ} \mathrm{C} / 30^{\circ} \mathrm{C}$ & 7 & 7 \\
\hline & & $38^{\circ} \mathrm{C} / 33^{\circ} \mathrm{C}$ & 63 & 50 \\
\hline & & 'otal & 70 & 70 \\
\hline \multirow[t]{3}{*}{$4 / 2010 / 2012$} & \multirow[t]{3}{*}{2012} & $35^{\circ} \mathrm{C} / 30^{\circ} \mathrm{C}$ & 7 & 7 \\
\hline & & $38^{\circ} \mathrm{C} / 33^{\circ} \mathrm{C}$ & 53 & 43 \\
\hline & & & 60 & 50 \\
\hline \multirow[t]{3}{*}{$5 / 2012 / 2013$} & \multirow[t]{3}{*}{2013} & $35^{\circ} \mathrm{C} / 30^{\circ} \mathrm{C}$ & 7 & 7 \\
\hline & & $38^{\circ} \mathrm{C} / 30^{\circ} \mathrm{C}$ & 35 & 35 \\
\hline & & otal & 40 & 40 \\
\hline
\end{tabular}

* The first number indicates the chronological number of candidate material taken into the scheme, the second shows the year of establishment of candidate plants, and the third indicates the year of thermotherapy.

tain humidity and kept in a growth chamber at $25^{\circ} \mathrm{C}$. When 3 to 4 leaves were produced, the jars were gradually removed, and plants were transferred to the greenhouse.

Detection of viruses. The presence of ApMV, ACLSV, ASGV, and ASPV in the mother trees and all candidate plants before and after thermotherapy was tested by RTPCR. Samples from mother trees (buds, leaves) were collected in May. Leaf samples from each candidate plant before thermotherapy were collected in April. Samples from candidate plants after the thermotherapy were collected starting from the next season after overwintering from April to June.

For total RNA isolation, approximately $100 \mathrm{mg}$ of frozen leaf tissues from each sample were grounded into a fine powder in liquid nitrogen and suspended in $200 \mu \mathrm{l}$ TE buffer. The extraction of RNA was carried out with a Genomic DNA Purification Kit (ThermoFisher Scientific, Lithuania) following the manufacturer's recommendations with minor modifications. DNA/RNA precipitation was done with cold $96 \%$ ethanol overnight instead of $10 \mathrm{~min}$ at $-20{ }^{\circ} \mathrm{C}$. The quantity and quality of the RNA were measured using a spectrophotometer NanoDropR ND-1000 (Thermo Scientific, USA). RNA was directly used for RTPCR assay or stored at $-80{ }^{\circ} \mathrm{C}$ until analysis.

RT-PCR assays were carried out with the OneStep RT-PCR kit (Qiagen AG, Germany) according to the manufacturer's instruction, using virus-specific primers $(0.6 \mu \mathrm{M})$ and Nad5 primers $(0.25 \mu \mathrm{M})$ as an internal control, which were obtained from Menzel et al., (2002). RT-PCR was carried out 
in a Mastercycler ${ }^{\circledR}$ thermocycler (Eppendorf AG, Germany). Cycling conditions were: reverse transcription step for $30 \mathrm{~min}$ at $50{ }^{\circ} \mathrm{C}$; activation of the HotStart Taq DNA polymerase at $95{ }^{\circ} \mathrm{C}$ for $15 \mathrm{~min}$, followed by 40 cycles of $94{ }^{\circ} \mathrm{C}$ for $30 \mathrm{~s}$, annealing at $55^{\circ} \mathrm{C}$ for $45 \mathrm{~s}, 72^{\circ} \mathrm{C}$ for $1 \mathrm{~min}$, and a final extension step at $72{ }^{\circ} \mathrm{C}$ for $10 \mathrm{~min}$. PCR products were separated by electrophoresis in $2 \%$ agarose gel in $1 \times$ TAE buffer, stained with ethidium bromide, and visualised under UV light. The size of RT-PCR products was determined by comparison with O'RangeRuler 100 bp DNA ladder (ThermoFisher Scientific, Lithuania).

Testing on woody indicators. Due to the availability of propagation material for woody indicators and candidate plants, tests on woody indicators were started gradually. In 2012, the first test was conducted, for infection of cultivars 'Ausma', 'Baltais Dzidrais', 'Spartan', 'Liberty', 'Lobo', 'Antej', 'Melba', 'Lobo', and 'Antonovka' by four viruses. Apple rootstocks 'Antonovka' were double-budded with the material to be tested and a woody indicator. Budding was performed during the growing season by inserting a dormant bud into a shallow slice under the rind of the tree according to Kirby et al. (2001). Three plants were established for each candidate plant from the each of the following woody indicators: Malus platycarpa for detection of ACLSV, M. pumila 'Virginia Crab' for detection of ASGV and ASPV, and M. pumila 'Lord Lambourne' for detection of ApMV. Indicators grafted on seedling rootstocks were used as negative control. Four scions from the tree of cultivar 'Rubin' showing symptoms of viral infections and previously confirmed to be infected with all four viruses were used to establish plants as positive controls. After budding, plants were kept in an insect-proof greenhouse with cooling facilities and temperature range $18-25^{\circ} \mathrm{C}$ to ensure correct

temperatures for symptom expression. Symptom appearance and expression was evaluated once a week after budding during eight weeks and the next vegetation season.

\section{RESULTS}

Plant survival. Survival of apple plants during the heat treatments varied from $45-100 \%$ depending on the thermotherapy conditions and plant genotype. The number of plants that overwintered to the next season after thermotherapy ranged from $12-62 \%$. Most of the plants from candidate materials $1 / 2007 / 2009$ and 2/2008/2010 did not overwinter to the next growing season after the thermotherapy; the remaining plants did not survive further winters and were lost (Table 2). The highest number of plants that survived the heat treatment and overwintered to further growing seasons was for candidate material 1/2012/2013 when the length of heat treatment was reduced to 40 days, adaptation period prolonged to seven days and age of plants subjected to the thermotherapy was one year (Tables 1,2 ).

Pears tolerated heat treatments better than apple, and $71-100 \%$ of pear plants, depending on candidate material, survived during the thermotherapy (Table 2). However, most of the pear candidate plants were lost during the first winter after thermotherapy and in following winters. The number of overwintered plants to the next season varied from $0-36 \%$ and only plants from candidate material 4/2010/2012 and 5/2012/2013 survived further winters (Table 2).

Detection of viruses by RT-PCR. Selection of mother trees in the field for apple from germplasm collections or pomological trials without virus infections was possible

Table 2

PLANT SURVIVAL DURING THE HEAT TREATMENTS AND OVERWINTERING OF APPLE AND PEAR CANDIDATE MATERIAL

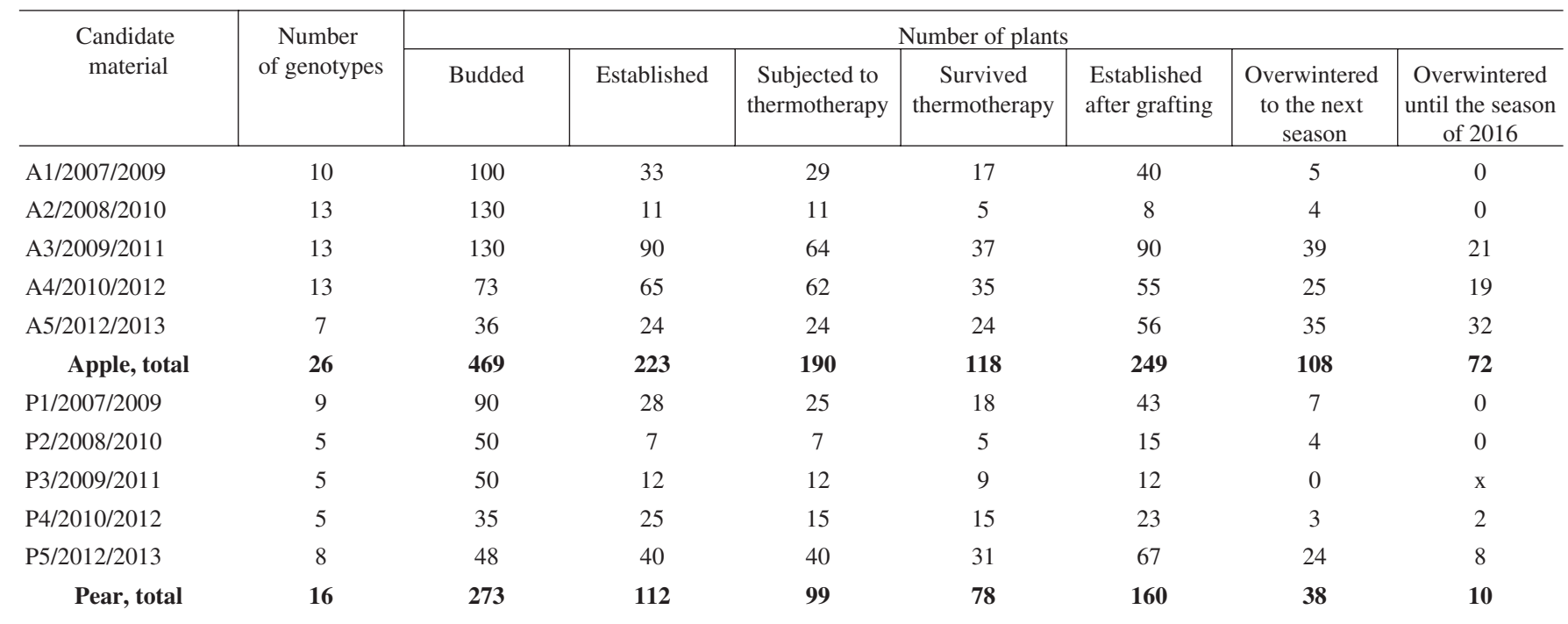

The letter and the first number indicate the chronological order and species of candidate material taken into the scheme, the second shows the year of establishment of candidate plants, and the third indicates the year of thermotherapy.

** The total number for apple or pear represents the number of genotypes that have been taken into the scheme, it is not a sum of genotypes for each candidate material since several genotypes were repeated. 
only for domestic cultivars 'Zane', 'Baiba', 'Gita', 'Edite', 'Roberts', 'Ligita', 'Dace', and 'Uldis' from recent breeding programmes and for a few introduced cultivars (Table $3)$. Other apple cultivars in most cases were infected with two or three viruses. Some apple cultivars, such as 'Rubin' and 'Ausma', were infected with all four tested viruses. Trees of selected pear cultivars were mostly infected with one virus or viruses were not detected (Table 4).

The established candidate plants were individually tested after budding on seedling rootstocks in the next season prior to thermotherapy. Similarly, as in mother trees in the field, the same viruses were detected in several of the established candidate plants of apple and pear. In some cases, other viruses than in mother trees were detected for both host species, such as ASGV in apple and ASGV and ASPV in pear (Tables 3,4). The established candidate plants of domestic apple cultivars from recent breeding programmes appeared to be infected with several viruses that were not detected in mother trees (Table 3).

For the candidate material $1 / 2007 / 2009$, no viruses were found in the next year after thermotherapy in all survived apple and pear plants subjected to the heat treatment for 40 days. However, ASGV and ApMV were detected in apple and pear, respectively, in the second season after thermotherapy. Extending exposure at high temperatures and heat treatment in general effectively eliminated ACLSV for most of the apple cultivars, but ASGV and ASPV were still detected in several plants (Table 3). For candidate material $4 / 2010 / 2012$, to increase the outcome of survived plants after the heat treatment, the length of thermotherapy was reduced (Table 1). After thermotherapy, some candidate plants of apple cultivars 'Dace' and 'Zarya Alatau' remained infected with ACLSV.

The duration of thermotherapy was shortened to 40 days and temperature was decreased during the dark period to 30 ${ }^{\circ} \mathrm{C}$ for candidate material 5/2012/2013 to improve plant vitality and promote faster growth. Newly established plants by shoot-tip grafting were tested in the next three seasons after the thermotherapy. In these conditions, ACLSV and ApMV were successfully eliminated from most of the infected apple and pear cultivars. However, similarly as in other years, individual plants of apple and pear were positive on ASGV or ASPV (Tables 3,4).

Testing on woody indicators. Individual plants of nine apple cultivars from candidate material 3/2009/2011, which were negative to all tested viruses in RT-PCR tests, were selected for testing on woody indicators for four widespread pome fruit viruses. In the first year, after eight weeks of double budding on indicators, none of the tested candidate plants showed symptoms characteristic of virus infections. Nevertheless, plants of $M$. platycarpa double budded with cultivar 'Rubin' on seedling rootstock and used as positive controls expressed chlorotic rings on leaves characteristic for ACLSV infection already two weeks after budding (Fig. 2B). Necrotic grooves in a flame-like pattern at the graft union indicating ASGV infection were observed on M. pumila
'Virginia Crab' double budded with cultivar 'Rubin' on seedling rootstock (Figure 3). Negative control plants of $M$. platycarpa and M. pumila 'Virginia Crab' did not express such symptoms and remained without any signs that would indicate viral infections (Fig. 2A). Symptoms of ASPV and ApMV were not expressed on woody indicators budded with a positive control.

\section{DISCUSSION}

The high temperature is widely used for virus elimination in plants, including for apple (Welsh and Nyland, 1965; Lenz and Lankes, 2006). High temperature can inhibit virus multiplication and movement in plant tissues; therefore thermotherapy can significantly improve virus elimination efficiency (Mink et al., 1998). However, the application of elevated temperatures and exposure time are limited due to the heat tolerance of plant species and genotypes (Stein et al., 1991). Pears are considered to be more sensitive to prolonged exposure to high temperature than other woody plant species (Paprstein et al., 2008). In our work pear tolerated heat treatment better than apple, especially if the length of exposure reached 70 days, when survived plants after treatments were about $70 \%$ and $45 \%$, respectively. The main problem for the establishment of nuclear stock material was the low survival of buds grafted on seedling rootstocks after thermotherapy and overwintering of newly established plants after the heat treatment. Therefore, many plants were lost during the first and also following winters.

The efficiency of the thermotherapy depends on different sensitivity of viruses to elevated temperatures (Campbell and Best, 1968) and subsequently on the reliability of the method used for detection of viruses in treated plants. Among methods used for detection of viral infections in plants, RT-PCR is considered as the most reliable and sensitive method (Reed and Foster, 2011). However, the efficiency of RT-PCR depends on the quality of extracted RNA, due to the high quantities of polyphenol compounds and polysaccharides in leaves of fruit trees that can inhibit RT-PCR (MacKenzie et al., 1997; Deng et al., 2004).
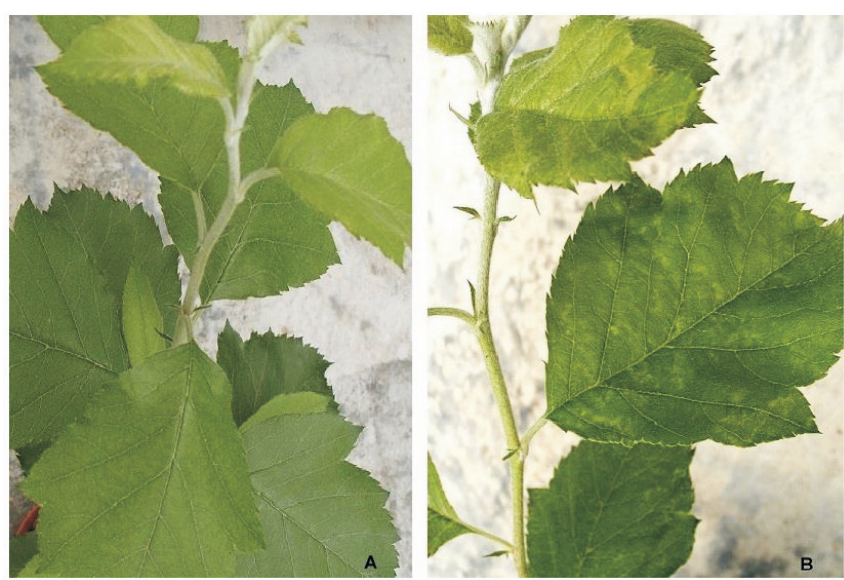

Fig. 2. Malus platycarpa double-budded on seedling rootstock with cultivar 'Rubin' showing chlorotic line pattern and rings (B) characteristic of Apple chlorotic leaf spot virus infection and control plant without scion from infected plant not showing symptoms (A). 
DETECTED VIRUSES IN MOTHER TREES AND CANDIDATE MATERIAL OF APPLE BEFORE AND AFTER THERMOTHERAPY

\begin{tabular}{|c|c|c|c|c|c|c|c|c|c|c|}
\hline \multirow[t]{2}{*}{$\begin{array}{l}\text { No. of candidate } \\
\text { material and cultivar }\end{array}$} & \multirow[t]{2}{*}{ Detected viruses in mother tree } & \multicolumn{4}{|c|}{$\begin{array}{l}\text { Number of infected candidate plants } \\
\text { before thermotherapy }\end{array}$} & \multicolumn{5}{|c|}{$\begin{array}{c}\text { Detected viruses and number of infected plants } \\
\text { after thermotherapy }\end{array}$} \\
\hline & & ACLSV & ApMV & ASGV & ASPV & $1^{\text {st }}$ year & $2^{\text {nd }}$ year & $3^{\text {rd }}$ year & $4^{\text {th }}$ year & $5^{\text {th }}$ year \\
\hline \multicolumn{11}{|l|}{ A1/2007/2009: } \\
\hline Antonovka & ACLSV & 2 & 0 & 2 & 1 & 0 & $\mathrm{x}$ & $\mathrm{x}$ & $\mathrm{x}$ & $\mathrm{x}$ \\
\hline Auksis & ACLSV, ASPV & 3 & 0 & 2 & 3 & 0 & $\mathrm{x}$ & $\mathrm{x}$ & $\mathrm{x}$ & $\mathrm{x}$ \\
\hline Ausma & ACLSV, ApMV, ASPV, ASGV & 0 & 0 & 2 & 3 & $\mathrm{x}$ & $\mathrm{x}$ & $\mathrm{x}$ & $\mathrm{x}$ & $\mathrm{x}$ \\
\hline Baltais Dzidrais & ACLSV, ASPV & $\mathrm{x}$ & $\mathrm{x}$ & $\mathrm{x}$ & $\mathrm{x}$ & $\mathrm{x}$ & $\mathrm{x}$ & $\mathrm{x}$ & $\mathrm{x}$ & $\mathrm{x}$ \\
\hline Liberty & ACLSV, ApMV, ASPV & 0 & 1 & 0 & 7 & $\mathrm{x}$ & $\mathrm{x}$ & $\mathrm{x}$ & $\mathrm{x}$ & $\mathrm{x}$ \\
\hline Saltanat & ACLSV, ASPV & 2 & 1 & 2 & 4 & $\mathrm{x}$ & $\mathrm{x}$ & $\mathrm{x}$ & $\mathrm{x}$ & $\mathrm{x}$ \\
\hline Sinap Orlovskij & ACLSV, ASGV, ASPV & 3 & 0 & 2 & 3 & 0 & 1-ASGV & $\mathrm{x}$ & $\mathrm{x}$ & $\mathrm{x}$ \\
\hline Spartan & ACLSV, ASGV, ASPV & $\mathrm{x}$ & $\mathrm{x}$ & $\mathrm{x}$ & $\mathrm{x}$ & $\mathrm{x}$ & $\mathrm{x}$ & $\mathrm{x}$ & $\mathrm{x}$ & $\mathrm{x}$ \\
\hline Zarja Alatau & ACLSV, ASGV, ASPV & 1 & 0 & 0 & 0 & $\mathrm{x}$ & $\mathrm{x}$ & $\mathrm{x}$ & $\mathrm{x}$ & $\mathrm{x}$ \\
\hline \multicolumn{11}{|l|}{ A2/2008/2010: } \\
\hline Antej & ACLSV, ASPV & $\mathrm{x}$ & $\mathrm{x}$ & $\mathrm{x}$ & $\mathrm{x}$ & $\mathrm{x}$ & $\mathrm{x}$ & $\mathrm{x}$ & $\mathrm{x}$ & $\mathrm{x}$ \\
\hline Antonovka & ACLSV & 0 & 0 & 0 & 0 & $\mathrm{x}$ & $\mathrm{x}$ & $\mathrm{x}$ & $\mathrm{x}$ & $\mathrm{x}$ \\
\hline Ausma & ACLSV, ApMV, ASGV, ASPV & 0 & 0 & 0 & 1 & $\mathrm{x}$ & $\mathrm{x}$ & $\mathrm{x}$ & $\mathrm{x}$ & $\mathrm{x}$ \\
\hline Baltais Dzidrais & ACLSV, ASPV & 0 & 0 & 0 & 0 & $\mathrm{x}$ & $\mathrm{x}$ & $\mathrm{x}$ & $\mathrm{x}$ & $\mathrm{x}$ \\
\hline Iedzēnu & ACLSV, ASGV, ASPV & $\mathrm{x}$ & $\mathrm{x}$ & $\mathrm{x}$ & $\mathrm{x}$ & $\mathrm{x}$ & $\mathrm{x}$ & $\mathrm{x}$ & $\mathrm{x}$ & $\mathrm{x}$ \\
\hline Koval̨enkovskoje & ACLSV, ASGV & 0 & 0 & 0 & 0 & $\mathrm{x}$ & $\mathrm{x}$ & $\mathrm{x}$ & $\mathrm{x}$ & $\mathrm{x}$ \\
\hline Liberty & ACLSV, ApMV, ASPV & 2 & 0 & 0 & 2 & $\mathrm{x}$ & $\mathrm{x}$ & $\mathrm{x}$ & $\mathrm{x}$ & $\mathrm{x}$ \\
\hline Rubin & ACLSV, ApMV, ASGV, ASPV & $\mathrm{x}$ & $\mathrm{x}$ & $\mathrm{x}$ & $\mathrm{x}$ & $\mathrm{x}$ & $\mathrm{x}$ & $\mathrm{x}$ & $\mathrm{x}$ & $\mathrm{x}$ \\
\hline Saltanat & ACLSV, ASPV & $\mathrm{x}$ & $\mathrm{x}$ & $\mathrm{x}$ & $\mathrm{x}$ & $\mathrm{x}$ & $\mathrm{x}$ & $\mathrm{x}$ & $\mathrm{x}$ & $\mathrm{x}$ \\
\hline Sinap Orlovskij & ACLSV, ASGV, ASPV & 0 & 0 & 0 & 1 & 0 & $\mathrm{x}$ & $\mathrm{x}$ & $\mathrm{x}$ & $\mathrm{x}$ \\
\hline Spartan & ACLSV, ASGV, ASPV & $\mathrm{x}$ & $\mathrm{x}$ & $\mathrm{x}$ & $\mathrm{x}$ & $\mathrm{x}$ & $\mathrm{x}$ & $\mathrm{x}$ & $\mathrm{x}$ & $\mathrm{x}$ \\
\hline Zarja Alatau & ACLSV, ASGV, ASPV & $\mathrm{x}$ & $\mathrm{x}$ & $\mathrm{x}$ & $\mathrm{x}$ & $\mathrm{x}$ & $\mathrm{x}$ & $\mathrm{x}$ & $\mathrm{x}$ & $\mathrm{x}$ \\
\hline \multicolumn{11}{|l|}{ A3/2009/2011: } \\
\hline Antej & ACLSV, ASPV & 0 & 1 & 0 & 0 & 0 & 0 & 0 & 0 & 0 \\
\hline Antonovka & - & 1 & 0 & 0 & 0 & 1-ApMV & 0 & 0 & 0 & 0 \\
\hline Auksis & ACLSV, ASPV & 8 & 4 & 0 & 0 & $\mathrm{x}$ & $\mathrm{x}$ & $\mathrm{x}$ & $\mathrm{x}$ & $\mathrm{x}$ \\
\hline Ausma & ACLSV, ApMV, ASGV, ASPV & 4 & 4 & 0 & 4 & 3-ASGV, 1-ASPV & 0 & 0 & 1-ASGV & 1-ASPV \\
\hline Kovalenkovskoe & ACLSV, ASGV & 8 & 2 & 0 & 0 & 0 & $\mathrm{x}$ & $\mathrm{x}$ & $\mathrm{x}$ & $\mathrm{x}$ \\
\hline Liberty & ACLSV, ApMV, ASPV, ASGV & 2 & 1 & 0 & 0 & 2-ASGV & 0 & 0 & 0 & 0 \\
\hline Lobo & - & 0 & 2 & 0 & 0 & 0 & 0 & 0 & 0 & 0 \\
\hline Melba & - & 0 & 0 & 0 & 0 & 2-ASGV & 0 & 0 & 0 & 0 \\
\hline Saltanat & ACLSV, ASPV & 4 & 1 & 0 & 0 & 0 & $\mathrm{x}$ & $\mathrm{x}$ & $\mathrm{x}$ & $\mathrm{x}$ \\
\hline Spartan & ASGV, ASPV & 0 & 0 & 6 & 0 & 1-ASPV & 0 & 0 & 0 & 0 \\
\hline \multicolumn{11}{|l|}{ A4/2010/2012: } \\
\hline Baiba & - & 0 & 0 & 1 & 0 & 0 & 0 & 0 & 0 & \\
\hline Dace & - & 2 & 4 & 0 & 1 & 1-ACLSV & \multicolumn{4}{|c|}{ 1-ACLSV 1-ACLSV 1-ACLSV } \\
\hline Edite & - & 0 & 3 & 0 & 0 & $\mathrm{x}$ & $\mathrm{x}$ & $\mathrm{x}$ & $\mathrm{x}$ & \\
\hline Gita & - & 0 & 0 & 1 & 0 & 0 & 0 & 0 & 0 & \\
\hline Konfetnoe & ACLSV, ApMV, ASGV, ASPV & 2 & 0 & 0 & 0 & 0 & 0 & 0 & 0 & \\
\hline Ligita & - & 0 & 1 & 0 & 0 & 0 & 0 & 0 & 0 & \\
\hline Rīgas Rožābele & ACLSV, ApMV, ASGV & 0 & 2 & 0 & 0 & $\mathrm{x}$ & $\mathrm{x}$ & $\mathrm{x}$ & $\mathrm{x}$ & \\
\hline Roberts & - & 0 & 2 & 1 & 0 & 0 & 0 & 0 & 0 & \\
\hline Rubin & ACLSV, ApMV, ASGV, ASPV & 4 & 5 & 5 & 3 & $\mathrm{x}$ & $\mathrm{x}$ & $\mathrm{x}$ & $\mathrm{x}$ & \\
\hline Saltanat & ACLSV, ASPV & 1 & 0 & 0 & 1 & 0 & 0 & 0 & 0 & \\
\hline Uldis & - & 0 & 2 & 0 & 0 & 0 & 0 & 0 & 0 & \\
\hline Zane & - & 0 & 2 & 0 & 0 & 0 & 0 & 0 & 0 & \\
\hline Zarja Alatau & ACLSV, ASGV, ASPV & 1 & 0 & 0 & 0 & 1-ACLSV & 0 & \multicolumn{3}{|c|}{ 1-ACLSV 1-ACLSV } \\
\hline \multicolumn{11}{|l|}{ A5/2012/2013: } \\
\hline Auksis & ACLSV, ASPV & 2 & 0 & 0 & 0 & 0 & 0 & 1-ASPV & & \\
\hline Edite & - & 0 & 1 & 0 & 0 & 0 & 0 & 0 & & \\
\hline Iedzēnu & ACLSV, ASGV, ASPV & 3 & 1 & 0 & 0 & 0 & 0 & 0 & & \\
\hline Kovalenkovskoe & ACLSV, ApMV, ASPV & 4 & 0 & 0 & 0 & 0 & 0 & 0 & & \\
\hline Rubin & ACLSV, ApMV, ASGV, ASPV & 2 & 0 & 1 & 1 & 1-ASGV & 0 & 0 & & \\
\hline Saltanat & ACLSV, ASPV & 1 & 0 & 0 & 0 & 0 & 0 & 0 & & \\
\hline Sinap Orlovskii & ACLSV, ASGV, ASPV & 1 & 0 & 0 & 0 & 0 & 0 & 0 & & \\
\hline
\end{tabular}

The letter and the first number indicate the chronological order and species of candidate material taken into the scheme, the second shows the year of establishment of candidate plants, and the third indicates the year of thermotherapy.

$\mathrm{x}$, plants did not survive thermotherapy or did not overwinter.

- , viruses not detected.

ACLSV, Apple chlorotic leaf spot virus; ApMV, Apple mosaic virus; ASGV, Apple stem grooving virus; ASPV, Apple stem pitting virus. 
DETECTED VIRUSES IN MOTHER TREES AND CANDIDATE MATERIAL OF PEAR BEFORE AND AFTER THERMOTHERAPY

\begin{tabular}{|c|c|c|c|c|c|c|c|c|c|}
\hline \multirow[t]{2}{*}{$\begin{array}{l}\text { No. of candidate material } \\
\text { and genotype }\end{array}$} & \multirow[t]{2}{*}{$\begin{array}{l}\text { Detected viruses } \\
\text { in mother tree }\end{array}$} & \multicolumn{4}{|c|}{$\begin{array}{l}\text { Number of infected candidate plants } \\
\text { before thermotherapy }\end{array}$} & \multicolumn{4}{|c|}{$\begin{array}{l}\text { Detected viruses and number of infected plants } \\
\text { after thermotherapy }\end{array}$} \\
\hline & & ACLSV & ApMV & ASGV & ASPV & $1^{\text {st }}$ year & $2^{\text {nd }}$ year & $3^{\text {rd }}$ year & $4^{\text {th }}$ year \\
\hline \multicolumn{10}{|l|}{ P1/2007/2009: } \\
\hline Belorusskaya Pozdnaya & - & 0 & 0 & 0 & 0 & 0 & 1-ApMV & $\mathrm{x}$ & $\mathrm{x}$ \\
\hline Concorde & ApMV & 0 & 0 & 4 & 4 & 0 & 0 & $\mathrm{x}$ & $\mathrm{x}$ \\
\hline Condo & ApMV & 1 & 0 & 0 & 0 & 0 & 0 & $\mathrm{x}$ & $\mathrm{x}$ \\
\hline Conference & ASPV & 0 & 0 & 1 & 1 & 0 & 0 & $\mathrm{x}$ & $\mathrm{x}$ \\
\hline Duyenne Du Comice & - & $\mathrm{x}$ & $\mathrm{x}$ & $\mathrm{x}$ & $\mathrm{x}$ & $\mathrm{x}$ & $\mathrm{x}$ & $x$ & $\mathrm{x}$ \\
\hline Mramornaya & ACLSV, ASGV & $\mathrm{x}$ & $\mathrm{x}$ & $\mathrm{x}$ & $\mathrm{x}$ & $\mathrm{x}$ & $\mathrm{x}$ & $\mathrm{x}$ & $\mathrm{x}$ \\
\hline $\mathrm{P} 67 / 21$ & ApMV & 0 & 0 & 0 & 0 & 0 & 1-ApMV & $\mathrm{x}$ & $\mathrm{x}$ \\
\hline Vasarine Sviestine & - & 0 & 0 & 0 & 4 & $\mathrm{x}$ & $\mathrm{x}$ & $\mathrm{x}$ & $\mathrm{x}$ \\
\hline Williams Bon Cretin & - & $\mathrm{x}$ & $\mathrm{x}$ & $\mathrm{x}$ & $\mathrm{x}$ & $\mathrm{x}$ & $\mathrm{x}$ & $\mathrm{x}$ & $\mathrm{x}$ \\
\hline \multicolumn{10}{|l|}{ P2/2008/2010: } \\
\hline Conference & ASPV & $\mathrm{x}$ & $\mathrm{x}$ & $\mathrm{x}$ & $\mathrm{x}$ & $\mathrm{x}$ & $\mathrm{x}$ & $x$ & $\mathrm{x}$ \\
\hline Eckehard & ASGV, ASPV & 0 & 0 & 0 & 0 & $\mathrm{x}$ & $\mathrm{x}$ & $\mathrm{x}$ & $\mathrm{x}$ \\
\hline Mramornaya & ACLSV, ASGV & 0 & 0 & 0 & 0 & $\mathrm{x}$ & $\mathrm{x}$ & $\mathrm{x}$ & $\mathrm{x}$ \\
\hline Noyabrskaya & - & 0 & 0 & 0 & 0 & $\mathrm{x}$ & $\mathrm{x}$ & $\mathrm{x}$ & $\mathrm{x}$ \\
\hline Vasarine Sviestine & - & 0 & 0 & 0 & 0 & 2-ASGV & $\mathrm{x}$ & $\mathrm{x}$ & $\mathrm{x}$ \\
\hline \multicolumn{10}{|l|}{ P3/2009/2011: } \\
\hline Eckehard & ASGV, ASPV & 0 & 0 & 0 & 0 & $\mathrm{x}$ & $\mathrm{x}$ & $x$ & $\mathrm{x}$ \\
\hline Mramornaya & ACLSV, ASGV & 0 & 0 & 0 & 1 & $\mathrm{x}$ & $\mathrm{x}$ & $\mathrm{x}$ & $\mathrm{x}$ \\
\hline Noyabrskaya & - & 0 & 0 & 0 & 0 & $\mathrm{x}$ & $\mathrm{x}$ & $\mathrm{x}$ & $\mathrm{x}$ \\
\hline Suvenir & ACLSV, ApMV, ASPV & 0 & 0 & 0 & 1 & $\mathrm{x}$ & $\mathrm{x}$ & $\mathrm{x}$ & $\mathrm{x}$ \\
\hline Vasarine Sviestine & - & 0 & 0 & 0 & 1 & $\mathrm{x}$ & $\mathrm{x}$ & $\mathrm{x}$ & $\mathrm{x}$ \\
\hline \multicolumn{10}{|l|}{ P4/2010/2012: } \\
\hline Jumurda & ASPV & 0 & 0 & 0 & 0 & $\mathrm{x}$ & $\mathrm{x}$ & $\mathrm{x}$ & $\mathrm{x}$ \\
\hline Mlijevskaya Rannaya & - & 2 & 0 & 0 & 2 & 0 & 0 & 0 & 0 \\
\hline Mramornaya & ACLSV, ASGV & 1 & 0 & 0 & 4 & 0 & 0 & 0 & 0 \\
\hline Pepi & ASPV & 0 & 0 & 0 & 0 & $\mathrm{x}$ & $\mathrm{x}$ & $\mathrm{x}$ & $\mathrm{x}$ \\
\hline Suvenir & ACLSV, ApMV, ASPV & 1 & 1 & 0 & 1 & $\mathrm{x}$ & $\mathrm{x}$ & $\mathrm{x}$ & $\mathrm{x}$ \\
\hline \multicolumn{10}{|l|}{ P5/2012/2013: } \\
\hline Conference & ASGV, ASPV & 0 & 0 & 0 & 0 & 0 & 0 & 0 & \\
\hline Jumurda & ACLSV & 2 & 0 & 1 & 4 & 0 & 0 & 1-ASPV & \\
\hline Mlijevskaja Rannaya & - & 0 & 1 & 0 & 0 & 0 & 0 & $\mathrm{x}$ & \\
\hline Mramornaja & ApMV & 0 & 1 & 0 & 0 & $\mathrm{x}$ & $\mathrm{x}$ & $x$ & \\
\hline Pepi & ASPV & 0 & 0 & 0 & 0 & 0 & 0 & $\mathrm{x}$ & \\
\hline Suvenir & ACLSV, ApMV, ASPV & 1 & 1 & 0 & 0 & $\mathrm{x}$ & $\mathrm{x}$ & $\mathrm{x}$ & \\
\hline Talsu Skaistule & - & 0 & 0 & 0 & 5 & 0 & 0 & 0 & \\
\hline Vasarine Sviestine & - & 0 & 0 & 0 & 0 & 0 & 0 & 0 & \\
\hline
\end{tabular}

The letter and the first number indicate the chronological order and species of candidate material taken into the scheme, the second shows the year of establishment of candidate plants, and the third indicates the year of thermotherapy.

$\mathrm{x}$, plants did not survive thermotherapy or did not overwinter.

- , viruses not detected.

ACLSV, Apple chlorotic leaf spot virus; ApMV, Apple mosaic virus; ASGV, Apple stem grooving virus; ASPV, Apple stem pitting virus.

Therefore, plant RNA is used as an internal control to verify PCR quality; this is especially important in the cases of negative results (Menzel et al., 2002). Thermotherapy is particularly associated with a long latent period before viruses can be detected and success of detection is related to the concentration of viruses in plant material (Leonhardt et al., 1998). In our work, this was evident for apple cultivar 'Auksis' and pear cultivar 'Jumurda' from candidate mate- rial 5/2012/2013. Test results were negative during the first years, and ASPV was detected only in the third year after the thermotherapy when virus titre in the plant tissues had reached the detectable level. Some candidate plants of apple cultivars 'Dace', 'Ausma', and 'Zarya Alatau' remained infected after thermotherapy, and test results were positive already in the first testing year. It seems that success of thermotherapy depends not only on the virus and conditions of 


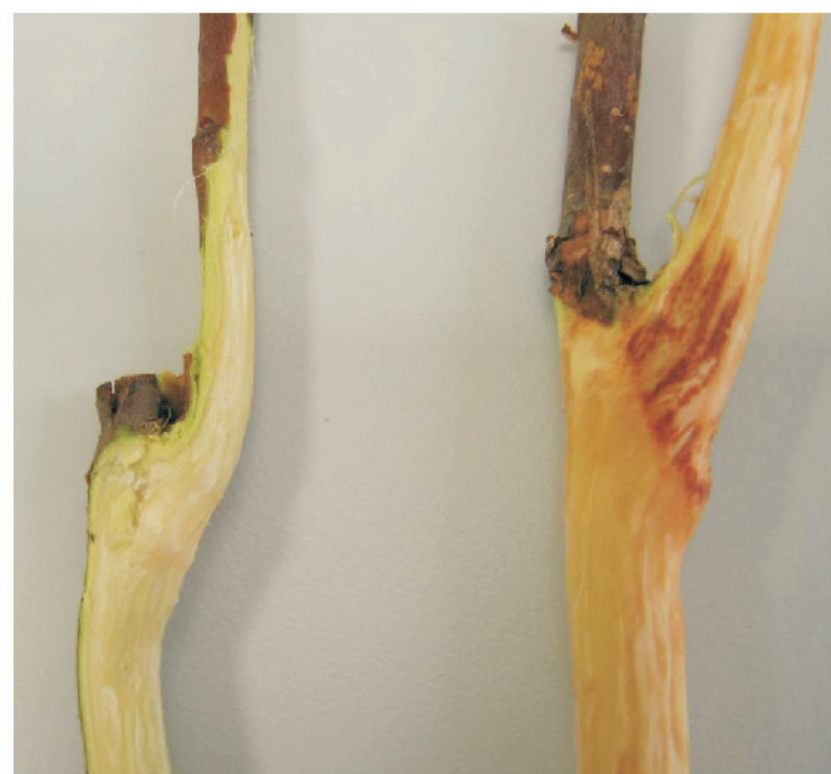

Fig. 3. Necrotic grooves in flame like pattern indicating ASGV infection at the graft union of seedling rootstock double budded with Malus pumila 'Virginia Crab' and cultivar 'Rubin' as positive control (right) and Malus pumila negative control (left).

heat treatment but also on the specific interaction between the virus and particular genotype, as also noted by Paprstein et al. (2008). Although ACLSV can be relatively easily eliminated from apple plants by a short period of heat treatment (Campbell and Best, 1964), in our study, apple cultivars 'Zarya Alatau' and 'Dace' remained infected with ACLSV after exposure at the elevated temperature for 60 days. ASGV and ASPV multiply in plant cambium and are unevenly distributed in plant tissues; therefore they are more difficult to eliminate and their detection is complicated (Desvignes, 1999; Gugerli and Ramel, 2003). ASGV is classified as a recalcitrant virus and heat does not effectively inhibit replication and distribution of the virus throughout the plant (Knapp et al., 1995). The testing of heat-treated plants for more than one season after the thermotherapy showed that ASGV and ASPV occasionally appear in apple cultivars 'Ausma', 'Baltais Dzidrais', 'Liberty', 'Melba', 'Spartan', and 'Rubin', and in later years they were even indeterminable in these cultivars. Maintaining of plants in protective conditions in the greenhouse can influence the uneven distribution of viruses in plants. Mixed infections of viruses in plants are more difficult to eliminate (Laimer and Barba, 2011). As shown in our previous studies (Pupola et al., 2011), pome fruit viruses are widely spread in Latvia due to propagation on infected clonal rootstocks and use of the scions from infected cultivars. Therefore, selection of mother trees without virus infections in orchards for propagation material was not possible in this work. Many cultivars were infected with at least two viruses and remained infected even after heat treatments for $60-70$ days. In mixed infections, ACLSV is more resistant to the heat (Knapp et al., 1995), which was also shown in our work for apple cultivars 'Dace' and 'Zarya Alatau', where ACLSV occurred in combination with two other viruses and was not eliminated by heat treatment. ApMV was detected in apple and pear mother plants in the field before thermotherapy and occasionally also after thermotherapy. ApMV is not stable and can disappear as a single infection in apples over the years without any treatment, as explained by Laimer and Barba (2011).

Among 72 apple and ten pear candidate plants that survived thermotherapy and overwintered, 63 plants from 24 apple cultivars and nine plants from six pear cultivars showed negative results on all four tested viruses during several years after thermotherapy with RT-PCR, and could be qualified as virus-tested nuclear stock plants. For nine apple cultivars, virus-free status was also evaluated on woody indicators in the greenhouse, and no virus infections have yet been confirmed for the tested plants. To confirm the virusfree status of candidate plants to all graft-transmittable diseases of apple and pear, testing on woody indicators in the field is necessary, which usually takes $2-3$ years to develop symptoms and up to 5 years before symptoms are assessed (Panattoni et al., 2013). As seen from experience in other countries, the development of virus-free nuclear stock of fruit trees leading to qualification according to all requirements is a long-term process requiring more than ten years (Van der Berg, 2003; Rowhani et al., 2005; Lenz and Lankes, 2006). This is mainly due to the time needed for propagation of trees, mixed virus infections that are difficult to eliminate, and the requirement for testing on woody indicators to confirm the virus-free status of candidate plants. The main reason for the low outcome of candidate nuclear stock plants in our work was the reduced cold tolerance of heat-treated plants during over-wintering in the greenhouse and mixed infections with several viruses in mother trees.

\section{ACKNOWLEDGEMENTS}

The work was financially supported from Latvian Ministry of Education and Science (2005), Latvian Ministry of Agriculture (2006-2009) and ERDF project 2010/0261/2DP/2.1.1.1.0/10/APIA/VIAA/155 (2011-2013).

We are grateful to Miroslawa Cieslinska and her colleagues at Institute of Horticulture (former Institute of Pomology and Floriculture) in Poland and colleagues from Institute of Horticulture in Lithuania for consulting at the beginning of our work, to Netherlands Inspection Service for Horticulture (Naktuinbouw) for providing propagation material of woody indicators, and to our colleagues at Institute of Horticulture for consulting or technical support during different steps of this work.

\section{REFERENCES}

Anonymous (1992a). Certification scheme. Virus-free or virus-tested fruit trees and rootstocks. Testing methods for viruses of fruit trees present in the EPPO region. EPPO Bulletin, 22, 265-275.

Anonymous (1992b). Council Directive 92/34/EEC on the marketing of fruit plant propagating material and fruit plants intended for fruit production. Available at: http://extwprlegs1.fao.org/docs/pdf/eur18958.pdf (accessed 21 September 2016) 
Anonymous (1999). Certification scheme. Pathogen-tested material of Malus, Pyrus and Cydonia. EPPO Bulletin, 29, 239-252.

Campbell, A. I., Best, M. W. (1964). The effect of heat therapy on several apple viruses. In: Annual Report Long Ashton Agricultural Horticultural Research Station 1963-1964. Long Ashton Research Station, Bristol, pp. $65-70$

Cembali, T., Folwell, R. J., Wandschneider, P., Eastwell, K. C., Howell W. E. (2003). Economic implications of a virus prevention program in deciduous tree fruits in the US. Crop Protection, 22 (10), 1149-1156.

Cieslinska, M., Zawadzka, B. (1999). Preliminary results of investigation on elimination of viruses from apple, pear and raspberry using thermotherapy and chemotherapy in vitro. Phytopathol. Pol., 17, 41-48.

Cropley, R. (1968). Comparison of some apple latent viruses. Ann. Appl. Biol., 61, 361-372.

Deng, X. Y., Hong, N., Hu, H. J., Wang, G. P. (2004). Detection of latent viruses in Pyrus pyrifolia by IC-RT-PCR and TC-RT-PCR. J. Fruit Sci., 21, 569-572.

Desvignes, J. C. (1999). Virus Diseases of Fruit Trees. Centre Technique Interprofessionnel des Fruits et Legumes, Paris. p. 202.

Fridlung, P. R. (Ed.) (1989). Virus and Viruslike Diseases of Pome Fruits and Simulating Noninfectious Disorders. Cooperative Extension College of Agriculture and Home Economics Washington State University Pullman, Washington. $330 \mathrm{pp}$.

Gugerli, P., Ramel, M. E. (2003). Production of monoclonal antibodies for the serological identification and reliable detection of apple stem pitting and pear yellow vein viruses in apple and pear. Acta Hortic., 657, 59-69.

Howell, W. E., Burgess, J., Mink, G. I., Skrzeczkowski, L. J., Zhang, Y. P. (1998). Elimination of apple fruit and bark deforming agents by heat therapy. Acta Hortic., 472, 641-646.

Jelkmann, W. (2001). International working group on fruit tree viruses. Acta Hortic., 550, 473-493.

Kaufmane, E., Skrīvele, M., Rubauskis, E., Strautiṇa, S., Ikase, L., Lācis, G., Seglina, D., Moročko-Bičevska, I., Ruisa, S., Priekule, I. (2013). Development of fruit science in Latvia. Proc. Latvian Acad. Sci., Section B, 67 (2), 71-83.

Kilevica, M., Svarcbahs, J., Kotans, G. (1976). Latent virus infections of apple and introduction of the system for growing healthy virus free planting material [Килевиц, М., Шварцбах, Я., Котанс, Г. Скрытая вирусная инфекция яблони и обоснование системы выращивания оздоровленного посадочного материала]. Proceedings of Latvia Academy of Agriculture [Труды Латвийской Сельскохозяйственной академии], 100, 26-31 (in Russian).

Kirby, M. J., Guise, C. M., Adams, A. N. (2001). Comparison of bioassays and laboratory assays for Apple stem grooving virus. J. Virol. Meth., 93 (1-2), 167-173.

Knapp, E., Hanzer, V., Weiss, H. H., Da Camara Machado, A., Weiss, B., Wang, Q., Katinger, H., Da Camara Machado, M. L. (1995). New aspects of virus elimination in fruit trees. Acta Hortic., 386, 409-418.

Laimer, M., Barba, M. (2011). Elimination of systemic pathogens by thermotherapy, tissue culture, or in vitro micrografting. In: Hadidi, A., Barba, M., Candresse, T., Jelkmann, W. (eds.). Virus and Virus-Like Diseases of Pome and Stone Fruits. APS Press, St. Paul, pp. 389-393.

Lenz, F., Lankes, C. (2006). Certification scheme for fruit trees in Germany. Latvian J. Agron., 9, 69-74.

Leonhardt, W., Wawrosch, C., Auer, A., Kopp, B. (1998). Monitoring of virus diseases in Austrian grapevine varieties and virus elimination using in vitro thermotherapy. Plant Cell Tiss. Org., 52, 71-74.

MacKenzie, D. J., McLean, M. A., Mukerji, S., Green, M. (1997). Improved RNA extraction from woody plants for the detection of viral pathogens by reverse transcription-polymerase chain reaction. Plant Dis., 81, 222-226.
Maxim, A., Zagrai, L., Zagrai, I., Isac, M. (2004). Studies on the influence of apple stem grooving virus on tree growth of various apple cultivars in the nursery. Acta Hortic., 657, 41-44.

Menzel, W., Jelkmann, W., Maiss, E. (2002). Detection of four apple viruses by multiplex RT-PCR assays with coamplification of plant mRNA as internal control. J. Virol. Meth., 99, 81-92.

Mink, G. I., Wample, R., Howell, W. E. (1998). Heat treatment of perennial plants to eliminate phytoplasmas, viruses, and viroids while maintaining plant survival. In: Hadidi, A., Khetarpal, R. K., Koganezawa, H. (eds.). Plant Virus Disease Control. APS Press, St. Paul, pp. 332-345.

Ostry, M. E., Hackett,W., Michler, C., Serres, R., McCown, B. (1994). Influence of regeneration method and tissue source on the frequency of somatic variation in Populus to infection by Septoria musiva. Plant Sci., 97, 5222-5226.

Panattoni, A., Luvisi, A., Triolo, E. (2013). Review. Elimination of viruses in plants: Twenty years of progress. Spanish J. Agricult. Res., 11 (1), 173-188.

Paprstein, F., Sedlak, J., Polak J., Svobodova, L., Hasssan, M., Bryxiova, M. (2008). Results of in vitro thermotherapy of apple cultivars. Plant Cell Tiss. Organ. Cult., 94, 347-352.

Posnette, A. F., Cropley, R. (1956). Apple mosaic viruses. Host reaction and strain interference. J. Hortic. Sci., 31, 119-133.

Pupola, N., Morocko-Bicevska, I., Kale, A., Zeltins, A. (2011). Occurrence and diversity of pome fruit viruses in apple and pear orchards in Latvia. $J$. Phytopathol., 159, 597-605.

Rani, V., Parida, A., Raina, S. N. (1995) Random amplified polymorphic DNA (RAPD) markers for genetic analysis in micropropagated plants of Populus deltoides Marsh. Plant Cell Rep., 14, 459-462.

Reed, P. J., Foster, J. A. (2011). Exclusion of pome and stone fruit viruses, viroids, and phytoplasmas by certification and quarantine. In: Hadidi, A., Barba, M., Candresse, T., Jelkmann, W. (eds.). Virus and Virus-Like Diseases of Pome and Stone Fruits. APS Press, St. Paul, pp. 382-388.

Rowhani, A., Uyemoto, J. K., Golino, D. A., Martelli, G. P. (2005). Pathogen testing and certification of Vitis and Prunus species. Annu. Rev. Phytopathol., 43, 261-278.

Skrivele, M., Kaufmane, E. (2015). The development of fruit-growing industry and science in Latvia [Skrīvele, M., Kaufmane, E. Aug̣̣kopības nozares un zinātnes attīstība Latvijā]. In: Ikase, L. (Ed.). The fruit-growing [Aug̣̣kopība]. LV Aug̣̣kopības institūts, Dobele, pp. 17-24 (in Latvian).

Skrivele, M., Kaufmane, E., Strautina, S., Ikase, L., Ruisa, S., Rubauskis, E., Blukmanis, M., Seglina, D. (2008). Fruit and berry growing in Latvia. In: Proceedings of International Scientific Conference "Sustainable Fruit Growing: From Plant to Product", 28-31 May 2008, Jūrmala - Dobele. Latvia State Institute of Fruit-Growing, Dobele, pp. 5-14.

Stein, A., Spiegel, S., Faingersh, G., Levis, S. (1991). Responses of micropropagated peach cultivars to thermotherapy for the elimination of Prunus necrotic ringspot virus. Ann. Appl. Biol., 119, 265-271.

Sutic, D. D, Ford, E. R., Tosic, M. T. (1999). Virus diseases of fruit trees. In: Sulzycki, J. (Ed.). Handbook of Plant Virus Diseases. CRC Press LLC, Boca Raton, pp. 321-389.

Svarcbahs J., Kilevica M., Miltins G. (1977). Heat treatment of apple trees infected with viruses [Шварцбах, Я., Килевица, М., Милтыньш, Г. Применение термотерапии в оздоовлении зараженных вирусами деревьев яблони]. Proceedings of Latvia Academy of Agriculture [Труды Латвийской Сельскохозяйственной академии], 153, 26-34 (in Russian).

Thompson, D., Howeel, W. E., Kolber, M. (2011). Biological indexing. In: Hadidi, A., Barba, M., Candresse, T., Jelkmann, W. (eds.). Virus and Virus-Like Diseases of Pome and Stone Fruits. APS Press, St. Paul, pp. 299-302.

Van den Berg, A. (2003). Certified nursery tree production in Holland. The Compact Fruit Tree, 36 (2), 43-45. 
Wang, L., Wang, G., Hong, N., Tang, R., Deng, X., Zhang, H. (2006). Effect of thermotherapy on elimination of apple stem grooving virus and apple chlorotic leaf spot virus for in vitro-cultured pear shoot tips. HortScience, 41 (3), 729-732.

Received 10 October 2016

Accepted in the final form 14 June 2017
Waterworth, H. E., Hadidi, A. (2005). Economic losses due to plant viruses. In: Hadidi, A., Khetarpal, R. K., Koganezawa, H. (eds.). Plant Virus Disease Control. APS Press, St. Paul, pp. 1-15.

Welsh, M. F., Nyland, G. (1965). Elimination and separation of viruses in apple clones by exposure to dry heat. Can. J. Plant Sci., 45 (5), 443-454.

\section{ĀBEḶU UN BUMBIERU ELITES AUGU KOLEKCIJAS IZVEIDE LATVIJĀ}

Ābeles un bumbieres ir vienas no svarīgākajām komerciālām aug̣̣augu sugām Latvijā. Galvenokārt audzē vietējās un no kaimiņvalstīm ievestās šķirnes, kuras ir piemērotas vietējiem klimatiskajiem apstākḷiem. Latvijā aug̣̣koku stādmateriāls, kas tiek pavairots un tālāk izmantots jaunu aug̣̣u dārzu izveidei, galvenokārt atbilst Conformitas Agraria Communitatis standartam, jo valstī nav pieejamas etalonaugu kolekcijas. Lai izveidotu vīrustestētu eksperimentālo ābeḷu un bumbieru etalonaugu kolekciju, vienu līdz divus gadu vecus kandidātaugus paḳ̣āva termoterapijai 40 līdz 70 dienas pie $+38{ }^{\circ} \mathrm{C}$. Mātes kokus un jaunos kandidātaugus pirms termoterapijas pārbaudīja uz četriem visizplatītākajiem aug̣̣koku vīrusiem ar RT-PCR. Pēc termoterapijas jauno dzinumu galotnes uzpotēja uz sēklaudžu potcelmiem un nākamo trīs līdz piecu veǵetācijas sezonu laikā, augus atkārtoti pārbaudīja ar RT-PCR. Pēc termoterapijas atseviški ābeḷu kandidātaugi šḳirnēm 'Dace', 'Zarja Alatau', 'Rubin' un 'Ausma' bija inficēti ar ābeḷu hlorotiskās lapu plankumainības vīrusu, ābeḷu stumbra rievainības vīrusu vai ābeḷu stumbra bedrainības vīrusu. Vīrustestētu ābeḷu un bumbieru etalonaugu kolekcijas izveidei, šobrīd tiek veikta izveidoto kandidātaugu pārbaude uz kokaugu indikatoraugiem, lai saskaṇā ar EPPO vadlīnijām noteiktu visus kaitīgos organismus, kuri tiek pārnesti ar inficētu pavairojamo materiālu. 